\title{
THE EFFECT OF SERVICE QUALITY ON CUSTOMER SATISFACTION IN GENIO MANADO HOTELS
}

\author{
Hartiny Pop Kopaha \\ Fakultas Ekonomi dan Bisnis Universitas Klabat \\ hartinikoapaha@unklab.ac.id
}

\begin{abstract}
The purpose of this research is to explain the variables which influence customers satisfaction at Genio Hotel Manado. The service quality like tangible, reliability, responsiveness, assurance and empathy influence the customers satisfaction. The data were taken from the guests who stay in Genio Hotel for March - May 2018. There were 120 respondences were taken and the data were analyzed by utilizing SPSS 16 to be analyzed by using Reliability Test, Validity Test, Multicollinearity Test and Heteroskedasticity Test, Analisis corelation, Coefficient determinant, Significant and Hypothesis in Likert Scale rating. The result of this research showed that there was significant influence of tangible, reliability, responsiveness, assurance and empathy of customers satisfaction. And for individual variable, tangible was the strongest variable influenced the customers satisfaction, and the second was responsiveness, reliability, and assurance but variable empathy was no significant influence to the customers satisfaction. The result showed that $78,6 \%$ was positive influence of the customers satisfaction and the rest $21,4 \%$ was from the other variable that were not in the area of this research.
\end{abstract}

Keywords: Assurance, emphaty, reliability, responsiveness, tangible, and customer satisfaction

\section{PENGARUH KUALITAS LAYANAN TERHADAP KEPUASAN KONSUMEN DI HOTEL GENIO MANADO}

\begin{abstract}
Abstrak
Tujuan dari penelitian ini adalah untuk menjelaskan variabel-variabel yang mempengaruhi kepuasan pelanggan di Genio Hotel Manado. Kualitas layanan seperti buki fisik, keandalan, daya tanggap, jaminan dan empati mempengaruhi kepuasan pelanggan. Data diambil dari para tamu yang menginap di Genio Hotel untuk bulan Maret - Mei 2018. Ada 120 responden yang diambil dan data dianalisis dengan menggunakan SPSS 16 untuk dianalisis dengan menggunakan Uji Reliabilitas, Uji Validitas, Uji Multikolinieritas, dan Uji Heteroskedastisitas, Analisis korelasi, Penentu Koefisien, Signifikan dan Hipotesis dalam penilaian Skala Likert. Hasil penelitian ini menunjukkan bahwa ada pengaruh yang signifikan antara bukti fisik, keandalan, daya tanggap, jaminan dan empati terhadap kepuasan pelanggan. Dan untuk variabel individu, bukti fisik adalah variabel terkuat yang mempengaruhi kepuasan pelanggan, dan yang kedua adalah daya tanggap, keandalan, dan jaminan tetapi variabel empati tidak berpengaruh signifikan terhadap kepuasan pelanggan. Hasil penelitian menunjukkan bahwa $78,6 \%$ adalah pengaruh positif dari kepuasan pelanggan dan sisanya $21,4 \%$ dari variabel lain yang tidak termasuk dalam wilayah penelitian ini.
\end{abstract}

Kata kunci: Jaminan, empati, keandalan, daya tanggap, bukti fisik, dan kepuasan pelanggan 


\section{Introduction}

Recently, there are lots of hotels in local areas including Manado city that accommodate both local and foreign guests to stay in. The efforts of a hotel in improving service is very important in order to make the guests satisfy and happy to stay in that place.

The tight competition of hotel and another inns can be seen from the increasing numbers of hotels in North Sulawesi, especially in Manado city. There are so many hotels are offering kinds of facilities and services in order to raise the amount of customers. Likewise, the competitor of Genio Hotel is not only provide the same facilities and services but also has more luxurious facilities, such as good room facilities, and more strategic location.

Genio Hotel is one of the hotels in the city of Manado that has been established for the past two years. It is located in downtown of Manado with a standard of two stars hotel. The Genio hotel business plan is to have a mission of providing good value to shareholders, employees and all customers who come and enjoy the hotel facilities by providing the best service for each guest.

Management considers that the services provided by the employees at the Genio hotel have not been maximized. Therefore, there are things that are needed to be done in order to solve this problem and in improving the excellent service at Genio hotels so as to increase the number of guests. By looking at the problems above, the author want to examine the effect of service quality toward the customer loyalty seen from the satisfaction dimension developed by Pasuraman called SERVQUAL (service quality) which is a measure of service quality, Tjiptono, (2007). The five dimensions include tangible dimensions, which is the appearance of hotel buildings, hotel building interiors and the appearance of hotel employees, the dimensions of reliability, including the hotel's ability to provide the best services, responsiveness dimensions, including the willingness of hotel employees to help consumers in serving more quickly, the assurance dimension, includes the courtesy of employees and their ability to generate a sense of reliability and trust in consumers, as well as an empathetic dimension, including personal care and attention given to consumers.

\section{Formulation of the problem}

Based on the background of the problem, this study formulates two research questions: a). Does the effect of service quality: Tangible, Reliability, Responsiveness, Assurance, and Empathy simultaneously affect customer satisfaction at Genio Hotel? b). Which service quality is the most dominant effect on customer satisfaction at Genio hotel?

\section{Significance of the Research}

This research is expected to be a material consideration and input for hotel management, academics, for consumers and for researchers. For Genio hotel, this research can be useful for companies or the top management in setting policies and strategies in the field of excellent service for the development of their business. For academic, this research can contribute to the academics as an additional literature on the influence of service quality in increasing customer satisfaction in the field of hospitality. For consumer hotel users, the results of this study can provide information to consumers how to choose a hotel that has a good level of service in order to improve customer satisfaction in the field of hospitality. For researcher, the results of this study can be a practical contribution in conducting research methods regarding the effect of service quality on customer satisfaction in the field of hospitality. 


\section{Theoretical framework}

Service is an activity that does not have a physical, can not be touched and is not visible to the eye given from one party to another, Malau (2017). Furthermore Malau (2017) explains that the friendliness of a flight attendant cannot be seen but can be felt. This means that service at the hotel is the same. A hotel receptionist who is friendly to serving his guests cannot be seen but can be felt by the guests.

Every hospitality company is being challenged to compete with the similar hotel units in order to increase sales. With the competition of every hotel that provides the best service for customers, the company must be very clever to adjust in order to survive in competition. Quality of service is one of the important factors for success with respect to customer satisfaction.

Service quality is defined as how far the difference between reality and customer expectations for services they receive Kotler (2007). The expectations of consumers are basically the same as what the company should give to its customers.

According to Tjiptono (2007) principally, the quality of services is focusing on efforts to meet the needs and desires of consumers, as well as the accuracy of delivery to offset customer expectations.

In order to find out whether consumers are satisfied or not, a measure that can be represented is needed, because in consuming a service offered through the provision, and improvement of service quality, consumers is expecting the good quality of services they will receive, so the measure that is used in estimating consumer satisfaction must include the underlying elements (Tjiptono, 2007). As stated by Kotler (2007), satisfaction can be interpreted as a feeling of satisfaction, a sense of pleasure and relief due to consuming a product or service to get the service of a service. If performance is below expectations, customers are not satisfied. If performance meets expectations, consumers are satisfied. If performance exceeds consumers, consumers are very satisfied or happy.

Definition of customer satisfaction is the level of state of one's feelings which is the result of a comparison between the assessment of the performance or the final product in relation to customer expectations. (Kotler \& Keller, 2013).

Basically the purpose of a business is to create satisfied customers. According toTjiptono (2008) the creation of customer satisfaction can provide several benefits, including the relationship between the company and the customer to be harmonious, providing a good basis for repurchasing and creating customer loyalty, and forming a recommendation from the mouth that is profitable for the company.

According to Lewis \& Boom (2008), service quality is a measure of how well the level of service provided is in accordance with customer expectations. Tjiptono (2007) further said that service quality is the expected level of excellence and control over the level of profitability to meet customer desires.

To facilitate research and measurement of service quality, a service quality measuring instrument was developed and is called SERQUAL (Service Quality). SERQUAL is a multi item scale that can be used to measure customer perceptions of service quality which includes five dimensions according to Zeithaml (2004). The five dimensions are:

1. Tangible (intangible), namely the ability of a company to show its existence to external parties. The appearance and capabilities of the company's physical facilities and infrastructure and the state of the surrounding environment are clear evidence of the services provided by the company.

2. Reliability, namely the ability to provide promised services promptly, accurately and satisfactorily. Performance must be in accordance with customer expectations which 
means timeliness, same service for all customers without errors, sympathetic attitudes and high accuracy.

3. Responsiveness, namely the ability to help and provide fast (responsive) and appropriate services to customers by delivering clear information and not allowing customers to wait without a clear reason that causes a negative perception in service quality.

4. Assurance (guarantee), the certainty or knowledge, courtesy, the ability of company employees to foster trust in customers to service the company.

5. Empathy (empathy), which is giving genuine and individual or personal attention given to customers by trying to understand the desires of consumers. Where a company is expected to have an understanding and knowledge of customers, understand customer needs specifically and have a comfortable operating time for customers.

Soesanto (2004) states that customer loyalty is a function of customer satisfaction, switching barriers and customer complaints. Satisfied customers will be able to make repeat purchases in the future and notify other people of the performance of the product or service they feel. Kotler (2013) said: "The long term success of the particular brand is not based on customers who purchase if only once, but on the number who become repeat purchase". In this case it can be concluded that loyal consumers are not measured by how much they buy, but from how often they make repeat purchases, including here recommending others to buy.

Service quality variable is the main variable chosen to influence customer satisfaction at the Genio Manado hotel.

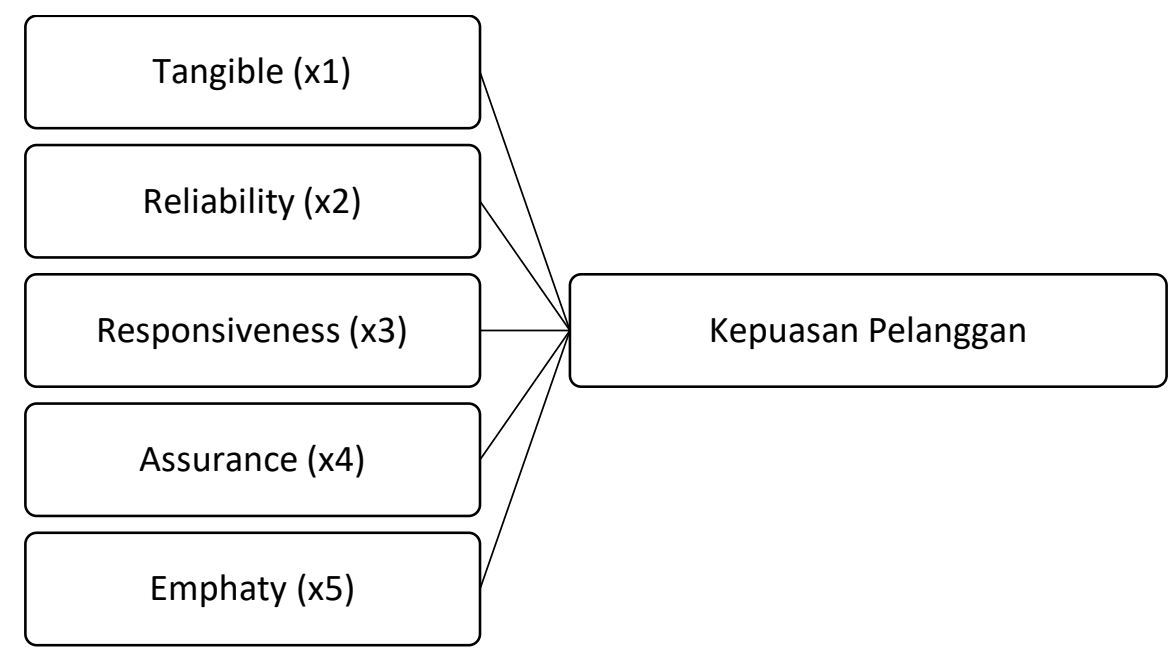

Figure 1

Conceptual Framework

Source: Kottler and Amstrong 2010

Notes:

Dependent Variable (Y): Customer Satisfaction

Independent Variable (X): Service Quality

Variable (X1) : Tangible

Variable (X2) : Reliability

Variable (X3) : Responsiveness

Variable (X4) : Assurance

Variable (X5) : Emphaty 


\section{Research Hypothesis}

Based on the formulation of the problem, the hypothesis that is used to answer the question is:

\section{Ho: Tangible, reliability, responsiveness, assurance and empathy simultaneously influence customer satisfaction at Genio hotels.}

\section{$H_{1}$ : Tangible, reliability, responsiveness, assurance and empathy partially influence customer satisfaction at Genio hotels.}

\section{Scope and Limitation of Problems}

The variables examined in this study are service quality namely Tangible, reliability, responsiveness, assurance and empathy as independent variables and customer satisfaction as dependent variables. The object of this research is guests at the Genio Manado hotel in the period starting in March 2018 - July 2018.

\section{Research Method}

\section{Research Design}

The design of this study descriptive methods and comparative causal methods. Descriptive method is a general procedure in a research that shows a phenomenon (Now \& Bougie, 2013). In accordance with Rivera and Rivera (2013), the descriptive method is research conducted by describing the variables and then try to draw conclusions. Whereas comparative casual research is a research with the characteristics of a problem in the form of causality between two or more variables Indriantoro, (2002). Causal comparative includes two or more groups and one independent variable as a research object between different subjects or times, then a cause and effect relationship is found. Multiple linear regression will be conducted to see the results of statistical tests obtained from the subject under study.

\section{Research Location}

Research Location. This research was conducted at the Genio Manado hotel, located at Jl. Sugiono No. 21, Wenang, Wenang Manado, North Sulawesi, Indonesia, 95122. Population and Samples: In this study the population used was Genio hotel customers, namely foreign customers and domestic customers, distributed questionnaires to them starting March 2018 July 2018. Population and the sample in this study as many as 120 people included hotel guests who came to stay between March 2018 to May 2018. In selecting samples, researchers used purposive sampling. This method is a technique of determining samples based on certain considerations or criteria. Samples that meet these criteria are non-random sampling methods where questions are given to every guest staying at the Genio hotel. Research Instrument: This study uses primary data by running a questionnaire to foreign and domestic hotel customers at the Genio Manado hotel. The questionnaire in this study used five points likert-scale questionnaires with answers that strongly disagree (1), disagree (2), neutral (3), agree (4) and strongly agree (5). This questionnaire modifies the research according to the existing theory. For details, see the attachment. The measuring instrument used is multiple linear regression to determine the effect of independent variables simultaneously on the dependent variable. The research instrument used SPSS software (Statistical Product and Service Solution). The high and low instruments show the extent to which the data collected does not deviate from the description of the intended variable. Arikunto (2002). 


\section{Technique Analysis / Statistical Test}

Cooper and Schindler (2010) describe multiple linear regression analysis showing a causal relationship between $\mathrm{X}$ variables (independent variables) which are causes and $\mathrm{Y}$ variables (non-independent variables) which are a result, and multiple linear analysis is a method used to describe the influence of variables free which affects the non-free variable.

Using the Heteroscedasticity Test, Multicollinearity Test, Validity Test and Reliability Test, by modifying the questionnaire from previous researchers, Sugiyono (2015), followed by testing the hypothesis using multiple linear regression. Validity test is used to measure the relationship or correlation between question indicators that measure an independent variable so that a questionnaire can be declared wrong or not. A questionnaire is said to be valid if the question in the questionnaire is able to express something measured by the questionnaire (Ghozali, 2013).

\section{Statistic Formula}

Hypothesis testing is carried out to see the influence between independent variables and dependent variables using the method of multiple regression analysis. The similarities include the following:

$$
\mathrm{KL}=\alpha+\beta 1 \mathrm{X} 1+\beta 2 \mathrm{X} 2+\beta 3 \mathrm{X} 3+\beta 4 \mathrm{X} 4+\beta 5 \mathrm{X} 5+\mathrm{e}
$$

Notes:

KL : Kualitas Layanan (Service Quality)

$\alpha$ : Konstanta

$\beta 1 \mathrm{~s} / \mathrm{d} \beta 5$ : Regression Coefficient of each variable

$\mathrm{X} 1$ : Tangible

$\mathrm{X} 2$ : Reliability

$\mathrm{X} 3$ : Responsiveness

$\mathrm{X} 4$ : Assurance

$\mathrm{X} 5$ : Empathy

e : Error factor

\section{Multicollinearity Test}

From the data collinearity statistics, the results obtained where the value of the variable $\mathrm{X} 1$ (tangible) gets the value of VIF 4.833 which is $\leq 10$; X2 (reliability) obtains a VIF value of 3.511 which is $\leq 10 ; \mathrm{X} 3$ (responsiveness) obtains VIF value 4,436 $\leq 10 ; \mathrm{X} 4$ (assurance) gets a VIF value of $4.042 \leq 10$ and X5 (empathy) obtaining a VIF value of $3.628 \leq 10$, this means that all independent variable data is multiculienear.

\section{Heteroscedasticity Test}

Heteroscedasticity test is a test that assesses whether there is an inequality of variance from the residual for all observations in the linear regression model. This union is one of the classic assumption tests that must be done in linear regression. If heteroscedasticity assumptions are not fulfilled, then the regression model is declared invalid as a forecasting tool.

The statistical image below shows that the variables under study are valid to run on the questionnaire because of the particular heteroscedasticity test

\section{Validity Test}

The validity test used in this study is the validity test of each item calculated on average which tests the quality of the items by calculating the correlation between each item with the 
total score as the validity criteria using Pearson Correlation where the Sig value $\leq 0.05$ then the data is valid. Sig Value from Price Factor - Promotional Factor in this study is the value of Sig (2-tailed) $0,000 \leq 0,05$. This shows that the factors studied are valid.

\section{Reliability Test}

The reliability test and validation test of the research instrument are intended so that the data obtained by means of questionnaires are valid and reliable. The instrument is said to be valid if it is able to measure what is desired and is able to reveal data that is examined appropriately. The high and low instruments show the extent to which the data collected does not deviate from the description of the variable in question Suharsimi Arikunto, (2002). 120 questionnaires were distributed, and all variables obtained reliable results where the tangible variable cronbach's alpha value was $0.843 \geq 0.6$; the reliability variable obtains the cronbach's alpha value of $0.764 \geq 0.6$; responsiveness variable with cronbach's alpha value of $0.783 \geq 0.6$; assurance obtains the cronbach's alpha value of $0.623 \geq 0.6$ and the empathic variable obtains the cronbach's value of $0.614 \geq 0.6$. These results indicate that all the variables studied are reliable. Data from statistical test results can be seen in the attachment.

\section{Results And Discussion}

From the results of statistical testing, the descriptive analysis of each variable can be summarized as will be explained in chapter IV.

\section{Statistical Testing}

Regression Test Results simultaneously or together, the variables X1 to X5 variables, namely tangible, reliability, responsiveness, assurance and empathy have a positive effect on customer satisfaction showing with ANOVA model, which the significant value $\leq 0.05$. The data can be seen in the table below:

Table 1

Anova

\begin{tabular}{llllll} 
Annova $^{\mathbf{a}}$ & & & & & \\
\hline Model & Sum of Squares & Df & Mean Square & F & Sig. \\
\hline Regression & 52,202 & 5 & 10,440 & 88,397 & $000^{\mathrm{b}}$ \\
Residual & 13,464 & 114 &, 118 & & \\
Total & 65,667 & 119 & & & \\
& & & & & \\
\hline
\end{tabular}

a. Dependent Variable: Kepuasan Pelanggan

b. Predictors: (Constant), Empathy, Reliability, Assurance, Responsiveness, Tangible

Partially or individually, the independent variable X1 - X4 has a significant effect on the dependent variable, namely $\mathrm{X} 1$ (tangible) has a significant value of $0,000 \leq 0.05 ; \mathrm{X} 2$ (reliability) has a value of $0.028 \leq 0.05 ; \mathrm{X} 3$ (responsiveness) has a value of $0.025 \leq 0.05$; and 
$\mathrm{X} 4$ (assurance) has a value of $0.035 \leq 0.05$; while the X 5 variable (empathy) does not partially affect customer satisfaction because it has a value of 0.708 or $\geq 0.05$. It means that the variables $\mathrm{X} 1$ to $\mathrm{X} 4 \mathrm{H} 1$ are accepted while X5, H1 are rejected. This can be seen from the unstandardized $\beta$ value in the table below:

Table 2

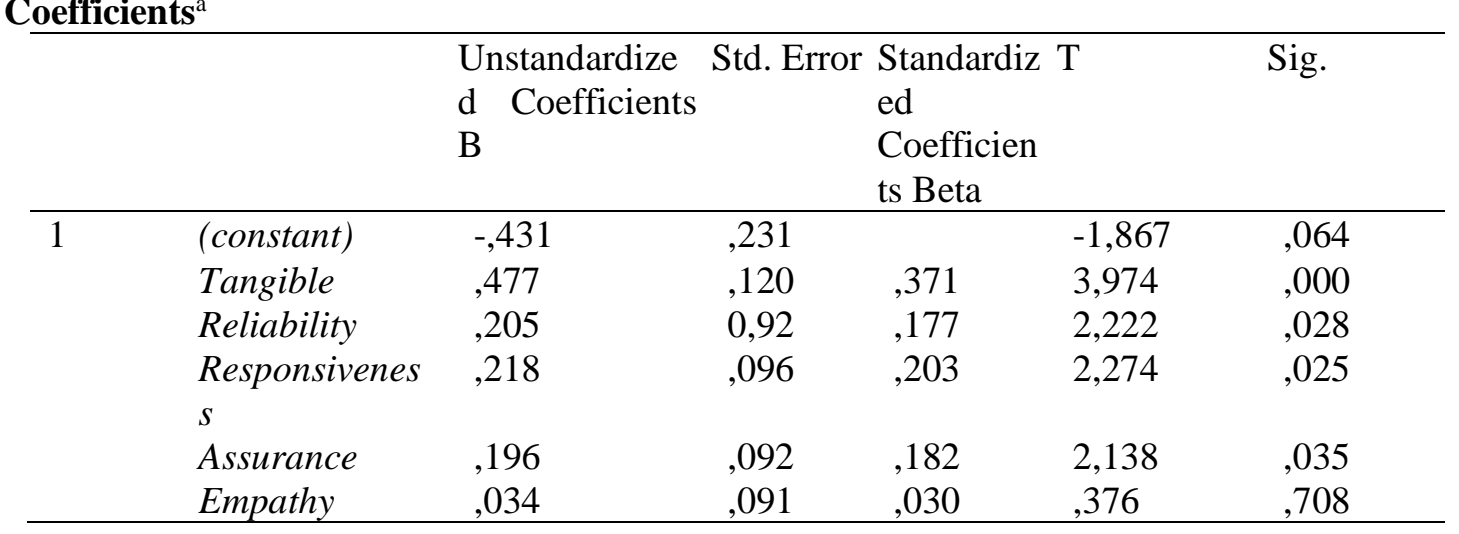

a. Dependent Variable: Customer Satisfaction

The table above can be elaborate as following:

The effects of the variables $\mathrm{X} 1$ to $\mathrm{X} 4$ variables are:

The first sequence is on X1 (tangible) variable, each increase of one unit X1 will increase customer satisfaction by 0.477 . The second sequence is the $\mathrm{X} 3$ variable (responsiveness) every increase of one unit X3 will increase customer satisfaction by 0.218 . Then the third sequence is on variable X2 (reliability), where each increase of one unit X2, will increase customer satisfaction by 0.205 . And the last sequence is in the $\mathrm{X} 4$ variable (assurance), where each increase of one unit X4 will increase customer satisfaction by 0.196 .

The results of this study are supported by Gulla, Oroh \& Roring (2015) and Wihanyuningsih (2010) which state partially that service quality has a positive effect on customer satisfaction partially.

Tabel 3

Model Summary of Multiple Regression Analysis

\begin{tabular}{lllll}
\hline Model & $\mathrm{R}$ & R Square & Adjusted R Square & Std. Error of the \\
& & & Estimate \\
\hline 1 &, $892^{\mathrm{a}}$ &, 795 &, 786 &, 34367 \\
\hline
\end{tabular}

a. Predictors: (Constant), Empathy, Reliability, Assurance, Responsiveness, Tangible

In the above table R-square or Adjusted $\mathrm{R}^{2}=0.786$, this means that the diversity that occurs in the dependent variable $\mathrm{Y}$ or customer satisfaction caused by variable $\mathrm{X}$ is equal to $78.6 \%$ which means that the independent variable $X$ has a positive effect of $78.6 \%$ on the 
dependent variable Y while the remainder is influenced by other variables not examined in this study.

From the results of the discussion above, simultaneously the variables tangible, reliability, responsiveness, assurance and empathy have a positive effect on customer satisfaction, which means that $\mathrm{H} 0$ is accepted. Then partially X1 (tangile), X2 (reliability), X3 (responsiveness) and $\mathrm{X} 4$ (assurance) variables have a positive effect on customer satisfaction $\mathrm{Y}$ variable while X5 (empathy) variable does not affect customer satisfaction Y variable which means $\mathrm{H} 1$ is rejected.

The results of this study are supported by Srijani (2017), at Aston Madiun hotel where the results of filling out questionnaires conducted by respondents as many as 101 people, there were 59 respondents who considered that the facility or tangible greatly affected customer satisfaction or $58.42 \%$. Likewise the research conducted by Kurniawan (2012), Novita and Nurchaya (2011) and Thomas (2008) who both stated that service quality consisting of accessibility, reliability, responsiveness, assurance and empathy had an effect on consumer satisfaction.

And results of this study are supported by Cronin et al., (2000), Bradi et al., (2005) that Service quality could have improved the customer satisfaction. Moreover the result of Kandampully (2007), and Clemens et al., (2009) that the consistent in making the service quality to customers greatly affected customer satisfaction.

\section{Conclusion}

Based on the discussion and analysis above, it can be concluded that partially, the tangible variable is a very strong variable or in the first places influences customer satisfaction at Genio Manado hotel. Reliability variables have a positive influence on the number three sequence of independent variables on customer satisfaction at the Genio Manado hotel. Similarly, the responsiveness variable has a positive effect on customer satisfaction at the Genio Manado hotel. The responsiveness variable is the variable number two strongest after the tangible factor. Assurance variables have a positive effect on customer satisfaction in Manado Genio Hotels, but this independent variable is the weakest variable or there is a fourth positive influence on customer satisfaction. While the empathy variable has a negative influence on customer satisfaction at the Genio Manado hotel. Simultaneously, the intangible, reliability, responsiveness, assurance and empathy variables have a positive effect on customer satisfaction at the Genio Manado hotel. Where there are $78.6 \%$ variables that affect customer satisfaction while $21.4 \%$ are influenced by other variables not examined in this study.

This study are supported by the theory of Gulla Rendy, Oroh, Sem George \& Roring Ferdy. (2015) about the effect of the service quality and the customer satisfaction and Lewis R.C. \& Boom, B.H. (2012) about the Serqual effected to the customer satisfaction. This results of the study are supported by the researchers Cronin et al., (2000), Bradi et al., (2005) and Srijani (2017) at the Hotel in Madiun and Kurniawan (2012), Novita and Nurchaya (2011).

\section{Suggestion}

Based on the result of the study, it is suggested that: the quality of empathy services is considered not to have an effect on the quality of service, so it is better for Genio hotels to strive to empathize with their customers, such as willingness to accept criticism, give more attention to hotel guests and establish good relations with hotel guests. Service quality, namely: tangible, reliability, responsiveness, assurance and empathy have a positive effect on customer satisfaction at the Genio Manado hotel. Suggestions for hotel management to continue to maintain the quality of these services so that the company's goals can be achieved because there 
are many guests who are satisfied by the services provided and adequate facilities provided by the hotel. Tangible service quality has the most impact on service quality, so it needs to be maintained in providing facilities to hotel guests. For further research, other variables that need to be studied should be given so that they may provide other results such as those that have not been studied before by using different tests.

\section{Daftar Pustaka}

Arikunto, Suharsimi. (2006), Prosedur Penelitian Suatu Pendekatan Praktik. Edisi Revisi V. Jakarta: Rineka Cipta.

Aryani, Dwi dan Febrina Rosinta. (2010), "Pengaruh Kualitas Layanan Terhadap Kepuasan Pelanggan dalam Membentuk Loyalitas Pelanggan", Bisnis \& Birokrasi, Jurnal Ilmu Administrasi dan Organisasi, Jakarta.

Brady Mikhael, G. Thomas (2005), "Removing The Contextual lens: A Multinational, Multi Setting Comparison of Service Evaluation Models" Journal Of Retailing Vol. 66 No. 1.

Buchari, Alma (2008), Manajemen Pemasaran Dan Pemasaran Jasa. Bandung: Alphabeta.

Clemens Michael. D, Jonathan Hung, Ce Wu, Bai Ding Hu, Christopher Han (2009) "An Empirical Study of Behavior Intentions In Taiwan Hotel Industry," Innovative Marketing Vol 5, issue No. 3.

Cronin, J.J. and Taylor, S.A. (2000), "Measuring service quality: a reexamination and Extension" Journal of Marketing, Vol. 56.

Cooper R.G., \& Schindler, J. (2010), Winning at new products: Creating Value Through innovation, 4th, New York, NY (Basic Book).

Ghozali, Imam. (2009), Aplikasi Analisis Multivariate Dengan Program IBM SPSS 19. Semarang: Badan Penerbit Universitas Diponegoro

Ghozali, Imam.(2013), Ekonometrika: Teori, Konsep dan Aplikasi dengan SPSS 17. Semarang: Badan Penerbit UNDIP.

Gulla Rendy, Oroh, Sem George \& Roring Ferdy. (2015). “Analisis Harga, Promosi, dan Kualitas Pelayanan Terhadap Kepuasan Konsumen pada Pada Hotel Manado Grace Inn," Jurnal EMBA: Jurnal Riset Ekonomi Manajemen, Bisnis dan Akuntansi 3(1).

I Komang Gede Mahendra. (2014), "Pengaruh Kualitas Layanan Terhadap Kepuasan Konsumen Pada Hotel Griya Sunset Kuta", Fakultas Ekonomi dan Bisnis Universitas Udayana, Ubud Bali - Indonesia.

Kotler, Philip dan Kevin Lane Keller, (2013). Marketing Management. Twelfth Edition New Jersey: Pearson Education. Inc. Jakarta: INDEKS.

Kotler, Philip and Gary Amstrong. (2014), Principles of Marketing Global 14th Edition. New Jersey: Prentice.

Kotler, Philip. (2007), Manajemen Pemasaran, Edisi 12, Jakarta: Pearson Education. Inc. Jakarta: INDEKS. 
Kotler, Philip \& Armstrong Garry. (2008), Prinsip-Prinsip Pemasaran. (Alih Bahasa, Bob Sabran). Jilid 1. Edisi keduabelas. Jakarta: Erlangga (Buku asli edisi 12).

Kurniawan, Adi. (2012), "Pengaruh Kualitas Layanan Terhadap Kepuasan Pelanggan Pos Express Di PT. Pos Indonesia (Persero) Kantor Pos Cukir". Jurnal Pendidikan Ekonomi, 1(1), 2-16.

Lewis R.C. \& Boom, B.H. (2012) “The Marketing Aspects of Service Quality”, Tjiptono Fandy, (2012), CV. Andi Offset.

Lubis, M. Saleh. (2013), "Pengaruh Kualitas Pelayanan Terhadap Kepuasan Pelanggan Arumas Hotel Lubuk Sikaping," e-Jurnal Apresiasi Ekonomi $1(2), 77-85$.

Lukita, Andreas (2017), "Pengaruh Kualitas Pelayanan Terhadap Keputusan Pelanggan Menginap Pada Hotel Duta di Lampung Utara," Studi Kasus Pada Fakultas Ekonomi dan Bisnis, Universitas Lampung, Bandar Lampung.

Mahendraswara, Krina \& Mudiantono, H. (2014), “Studi Terhadap Kualitas Pelayanan di Hotel Grand Candi Semarang," Universitas Diponegoro Semarang: eprints.undip.ac.id.

Malau, Harman. (2017). Manajemen Pemasaran, Teori dan Aplikasi Pemasaran Era Tradisional sampai Era Modernisasi Global. Bandung: Alfabeta

Manoppo, Ferninda. (2013). "Kualitas Pelayanan Dan Servicescape Pengaruhnya Terhadap Kepuasan Konsumen Pada Hotel Gran Puri Manado," Jurnal EMBA: Jurnal Riset Ekonomi, Manajemen Bisnis dan Akuntansi 1(4). ejournal.unsrat.ac.id.

Ninik Srijani \& Ahmad Sukma Hidayat. (2017), "Pengaruh Fasilitas Terhadap Kepuasan Pelanggan di Aston Madiun Hotel dan Conference Center," Jurnal Penelitian Ilmu Ekonomi WIGA, 7 (3), 31-38.

Normasai, Selvy. (2013). "Terhadap Kepuasan Pelanggan, Citra Perusahaan Dan Loyalitas Pelanggan, Survei Pada Tamu Pelanggan Yang Menginap Pada Hotel Pelangi Malang," Jurnal Administrasi Bisnis, 6(2).

Novita, Indri \& Nurcahaya. (2011). "Pengaruh Dimensi Kualitas Pelayanan Jasa Terhadap Kepuasan Pelanggan D\&I Skin Centre Denpasar. Jurnal Manajemen. Fakultas Ekonomi Universitas Udayana.

Rivera, M., \& Rivera, R. (2013). Particular Guide, to Thesis and Dissertation Writing.

Sekaran \& Bougie (2013), Research Method for Business: A Skill Building Approach, Southern Illinois University, New York: John Wiley \& Sons, Inc.

Sugiyono. (2015), Metode Penelitian Kuantitatif Kualitatif dan $R \&$ D. Bandung: Alfabeta.

Sulastiyono Agus. (2001). Manajemen Penyelenggaraan Hotel. Edisi Pertama Bandung: Alfabeta.

Soesanto. (2004). Mengukur Tingkat Kepuasan Pelanggan, Yogyakarta: Andi Offset. 
Thomas, Stefanus. (2008), "Analisa Kesenjangan Kualitas Pelayanan Dan Kepuasan Konsumen Pengunjung Plaza Tunjungan Surabaya," Jurnal Manajemen dan Kewirausahaan, 10(1), 66-83.

Tjiptono Fandy, dan Gregorius Chandra. (2007). Service, Quality and Safaction Yogyakarta: Andi Offset.

Tjiptono Fandy. (2008), Strategi Pemasaran. Edisi III. Yogyakarta: C.V Andi Offset.

Tjiptono Fandy. (2007), Pemasaran Jasa, Malang: Bayumedia Publishing.

Winahyuningsih, Panca (2010), "Pengaruh Kepercayaan Dan Kualitas Pelayanan Terhadap Kepuasan Konsumen Pada Hotel Griptha Kudus," Scholar.google.co.id, Jurnal Sosial Budaya 3(2).

Zeithaml, Valerie (2004), Service Marketing, Edisi III, Tata. New Delhi: McGraw Hill. Deghan, A. 